UDC 547.2/4; 917/.918;544.4

\title{
RESEARCH INTO KINETIC REGULARITIES OF CATALYTIC LIQUID-PHASE OXIDATION OF n-HEXADECANE IN THE PRESENCE OF METALCOMPLEXES CALALYSTS
}

\author{
R.H. Suleymanova, N.A. Zeynalov, O.T. Badalova, L.N. Qulubayova, \\ A.R. Guliyeva, N.A. Kerimova \\ Acad. M.Nagiyev Institute of Catalysis and Inorganic Chemistry \\ 113, H.Cavid ave., AZ 1143, Baku, Azerbaijan, e-mail: suleyman.rena@gmail.com
}

Received 19.05.2019

\begin{abstract}
Kinetic regularities of catalytic liquid-phase oxidation of $n$-hexadecane in the presence of metal complexes of variable valence were studied. In the reaction of $n$-hexadecane oxidation as a catalytic mixture, a complex o-phenanthroline with stearate with variable valence metals $(\mathrm{Mn} 2+, \mathrm{Cu} 2+, \mathrm{Co} 2+)$ was used. It found that o-phenanthroline significantly influences the catalytic activity of metal ions. The introduction of organic ligand into the catalytic system, as well as varying the ligand: metal salt ratio, has effect greatly on the course and character of the process.

Keywords: n-hexadecane, oxidation, liqand, o-phenanthroline, metal complex catalysis, metal, oxygen, liquid phase, complex
\end{abstract}

DOI: 10.32737/2221-8688-2019-3-417-422

\section{Introduction}

It is well-known, that polymers containing functional groups as the bearers are widely used for immobilization the number of complex-making sorbents, catalysts and biologically active substances [1-3]. The catalytic properties of such metal-polymer complexes were studied in the oxidation reactions of some paraffins and cycloparaffins and it was revealed, that they are higheffective catalyst $[4,5]$.

Side by side with metalpolymer catalysts in the reactions of liquid-phase oxidation of hydrocarbons, there are thoroughly explored metal-complex catalysts where combination and selection of appropriate ligands and donoracceptor additives make it possible to modify the structure and properties of the catalyst.

It should be noted that the quantitative combination of ligands and metals makes it possible to run the process at a certain stage where one product is mainly formed to thus remove the presence of many parallel and successive reactions as is the case with oxidation process [6-7]. The real raw material as an initial product for the production of synthetic fat acids (SFA) is a complicated mixture of paraffin hydrocarbons with different molecular weight and some insignificant admixtures of izoalkane, naphthene and aromatic compounds. In the course of oxidation these hydrocarbons behave not identically. Therefore, it is useful to start with analysis of individual hydrocarbons' behavior while studying their kinetic regularities, mechanism and chemism of the process. The obtained data make possible to put and correctly settle the problem of exploring the complicated composition of the initial raw material.

In the industrial production of SFA they very frequently use salts of metals with variable valence and insignificant admixtures of alkali metals as catalysts.

We have studied kinetic regularities of $n$ decane catalytic oxidation in the sphere of metal complexes with variable valence, and a number of regularities were discovered to be possibly identical with the oxidation of real paraffin mixture [8]. In the reactions of $n$ decane oxidation, the o-phenanthroline complex with manganese stearate was used as a catalytic mixture. It is well-known that o- 
phenanthroline strongly affects the catalytic activity of metal ions. A number of works has been mentioned in references where the course and character of oxidative processes containing o-phenanthroline in the catalytic composition were examined [9-10].

In this connection, the paper studies the catalytic activity of o-phenanthroline complexes with stearates of variable valence metals $\left(\mathrm{Mn}^{2+}, \mathrm{Cu}^{2+}, \mathrm{Co}^{2+}\right)$ in the liquid-phase oxidation of a typical representative of paraffin hydrocarbons - n-hexadecane that is in composition of the fraction $\mathrm{C} 10-\mathrm{C} 20$, which are the initial raw materials for SFA production.

The obtained in this research data of regularities can correctly reflect a real picture of oxidation course for rather complicated paraffin raw material.

\section{Experimental part}

The reaction of $n$-hexadecane oxidation has been carried out in a staging type glass reactor whith Scott filter, at atmosphere pressure and a temperature of $140^{\circ} \mathrm{C}$, had different ratio of organic ligand and metal compounds with variqable valence. Oxygen served as an oxidation agent. The oxidation was carried out by meams of catalyzated and non-catalyzated systems. As a catalyst we have chosen o-phenanthroline with stearate of manganese, cobalt and copper. The catalyst was put into a reactor in the stream of inert gas. Note that n-hexadecane was refined from possible admixtures and distillated at boiling point. In the course of oxidation we selected the samples that had been checked on hydroperoxides, acids and alcohols. The formation of hydroperoxides was established by iodometric method; that of carbonyl compounds - by infrared spectrometry method at a stripe of 1718-1720 sm . The alcohols were transformed into their corresponding alkyl nitrites and analyzed using the method of ultraviolet spectroscopy [11].

\section{Discussion of results}

The experimental results are presented in the figures below. As can be seen from the figures $(1,2)$ when manganese stearate is added to the non-catalyzed system, the decomposition of hydroperoxides sharply increases, which leads to the accumulation of alcohols. The ratio of the catalyst mixture plays a significant role in the direction of the reaction. The addition of 0 -

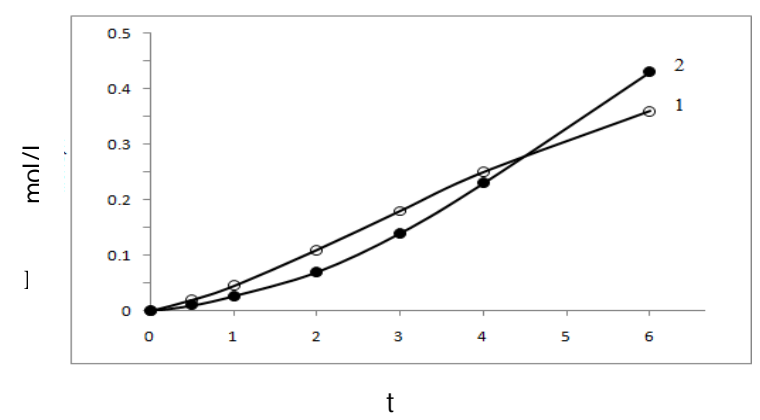

Fig.1. Non-catalyzated oxidation of n-hexadecane. presence. $\mathrm{T}=140^{\circ} \mathrm{C}, 1$-hydroperoxides, 2 -acids. phenanthroline promotes the dissolution of manganese salts and the catalyst, while remaining in the homogenized state, does not precipitate. Obviously, this state of the catalyst affects the course of the reaction, which proceeds selectively and with a large yield of alcohols (fig.3, 4 ).

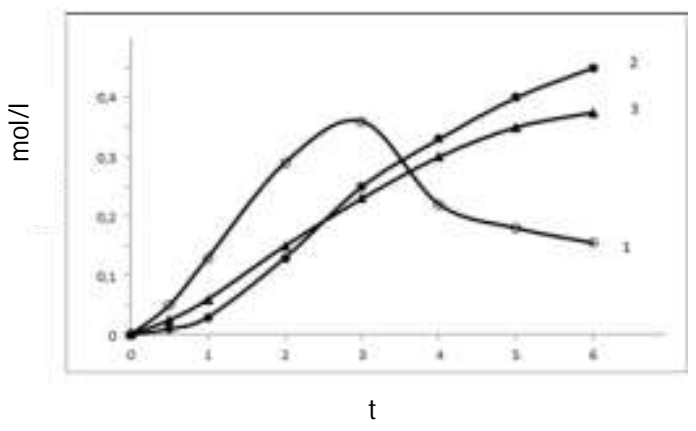

Fig. 2. N-hexadecane oxidation in manganese stearate $\mathrm{T}=140^{\circ} \mathrm{C}, 1$-hydroperoxides, 2 -acids, 3 -alcohols 


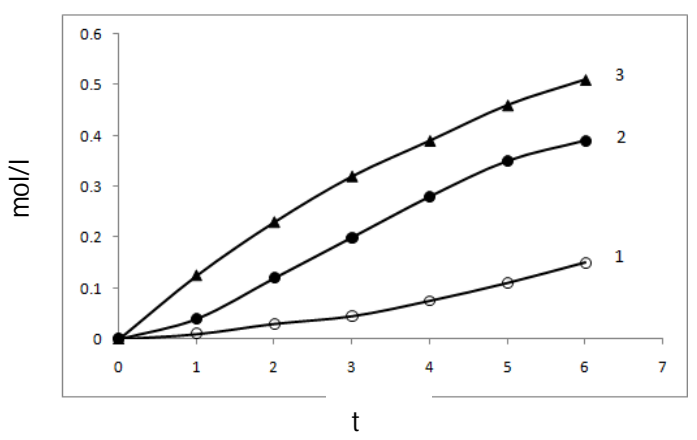

Fig.3. $n$-Hexadecane oxidation in the presence of complex o-phenanthroline with manganese stearate, $\mathrm{T}=140^{\circ} \mathrm{C}$, o-phen. $+\mathrm{Mn}(\mathrm{St})_{2}=1: 1$.

1.hydroperoxides, 2-acids, 3- alcohols.

The liquid phase oxidation of $n$-hexadecane in the presence of complexes of o-phenanthroline with manganese stearate in the ratio of 0 phenanthroline: manganese stearate $(0.0450$ :

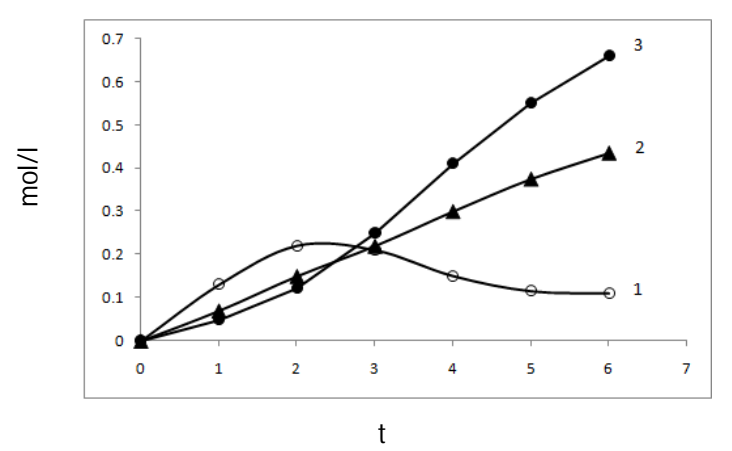

Fig.4. n-Hexadecane oxidation in the presence of complexs o-phenanthroline with manganese stearate, $\mathrm{T}=140^{\circ} \mathrm{C}$, o-phen. $+\mathrm{Mn}(\mathrm{St})_{2}=20: 1$.

1.hydroperoxides, 2-acids, 3- alcohols.

0.0153) $\mathrm{g}$ showed that the decomposition of hydroperoxides leads to the formation of mainly carbonyl compounds (Fig. 5).

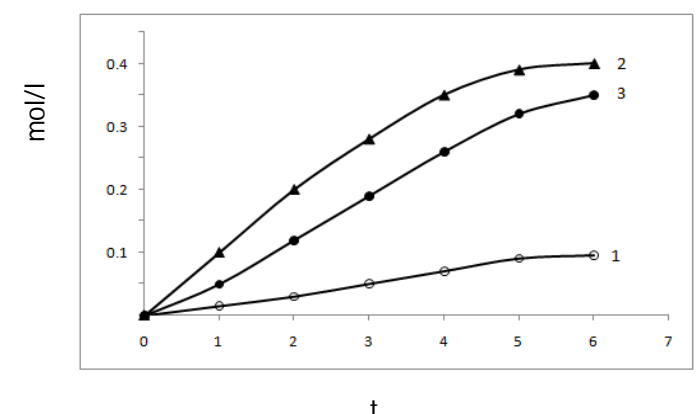

Also, an oxidation of n-hexadecane in the presence of o-phenanthroline with copper stearate was carried out. Note that the formation of hydroperoxides is more than $60 \%$. The complexes of o-phenanthroline with copper ions promote accumulation and stabilization of hydroperoxides. The results of experiment were presented in Table below. As is seen, copper salts display high initiative ability. Rates of accumulation in a number of intermediate products are perceptible. However, despite hydrocarbons conversion, selectiveness of each product is insignificant. The variety in catalytic system by the ratio of metal and organic ligands showed that the quantity of the latter influences greatly the nature of hydrocarbons oxidation. Introduction of a small quantity of ophenanthroline into the catalyst composition slows rates of the formation of reaction products. The same is true of high concentration of organic ligands as well. An optimum concentration of o-
Fig.5. N-hexadecane oxidation in the presence of complex ophenanthroline with manganese stearate, $\mathrm{T}=140^{\circ} \mathrm{C}$, o-phen $+\mathrm{Mg}(\mathrm{St})_{2}=(0.0450+0.0153) \mathrm{g}$

1.hydroperoxides. 2.carbonyl complexes, 3 . acids

phenanthroline promotes the formation of hydroperoxides and their stabilization. Thermal destruction of the latter leads to the accumulation of carbonyl compounds. Note that changes in metal concentration also influence the character of oxidation.

The yield of the products of reaction hydrocarbon oxidation and selectiveness of the process on hydroperoxides are also shown in Table. As follows data presented, there is a stabilization of hydroperoxides at a certain ratio of o-phenanthroline with copper ions.

The results of experiment, which was carried out in the presence of complexes o-phenanthroline with cobalt stearate, testify about the presence on a certain stage of oxidation ( 2 and 3 hours) the high rate of accumulation hydroperoxides. Their decomposition leads to predominance of carbonyl compounds concentration as well. 
Table. n-Hexadecane oxidation in the presence of o-phenanthroline complexes with variable valence metals

\begin{tabular}{|c|c|c|c|c|c|c|c|c|}
\hline № & $\begin{array}{l}\text { o-phe- } \\
\text { nanthro- } \\
\text { line, }(\mathrm{g})\end{array}$ & $\begin{array}{c}\text { Metals } \\
\text { stearate, } \\
(\mathrm{g})\end{array}$ & $\begin{array}{c}\text { Duration } \\
\text { of } \\
\text { reaction, } \\
(\mathrm{h})\end{array}$ & $\begin{array}{c}\text { Hydroper } \\
\text { oxides, } \\
(\mathrm{mol} / \mathrm{l})\end{array}$ & $\begin{array}{c}\text { Ketones, } \\
(\mathrm{mol} / \mathrm{l})\end{array}$ & $\begin{array}{l}\text { Alcohols, } \\
(\mathrm{mol} / \mathrm{l})\end{array}$ & $\begin{array}{l}\text { Acids, } \\
(\mathrm{mol} / \mathrm{l})\end{array}$ & $\begin{array}{l}\text { Selecti- } \\
\text { veness on } \\
\text { hydrope- } \\
\text { roxides, } \\
(\mathrm{mol} / \mathrm{l})\end{array}$ \\
\hline 1 & 0.0450 & $0.0145 \mathrm{Cu}^{2+}$ & 2.0 & 0.196 & 0.092 & 0.060 & 0.044 & 50.05 \\
\hline 2 & 0.0450 & $0.0145 \mathrm{Cu}^{2+}$ & 3.0 & 0.260 & 0.124 & 0.092 & 0.083 & 50.05 \\
\hline 3 & 0.0900 & $0.0145 \mathrm{Cu}^{2+}$ & 3.0 & 0.214 & 0.129 & 0.075 & 0.060 & 44.77 \\
\hline 4 & 0.0452 & $0.0141 \mathrm{Co}^{2+}$ & 2.0 & 0.196 & 0.064 & 0.0102 & 0.031 & 49.87 \\
\hline 5 & 0.0452 & $0.0141 \mathrm{Co}^{2+}$ & 3.0 & 0.256 & 0.100 & 0.145 & 0.069 & 44.91 \\
\hline 6 & 0.0452 & $0.0070 \mathrm{Cu}^{2+}$ & 3.0 & 0.270 & 0.089 & 0.062 & 0.045 & 57.94 \\
\hline 7 & 0.0450 & $0.0100 \mathrm{Cu}^{2+}$ & 3.0 & 0.240 & 0.072 & 0.059 & 0.066 & 54.92 \\
\hline 8 & 0.0675 & $0.0100 \mathrm{Cu}^{2+}$ & 3.0 & 0.170 & 0.042 & 0.040 & 0.029 & 60.50 \\
\hline
\end{tabular}

According to the scheme repeatedly alcohols are the products of hydroperoxides confirmed by experimental materials, the transformation [10].

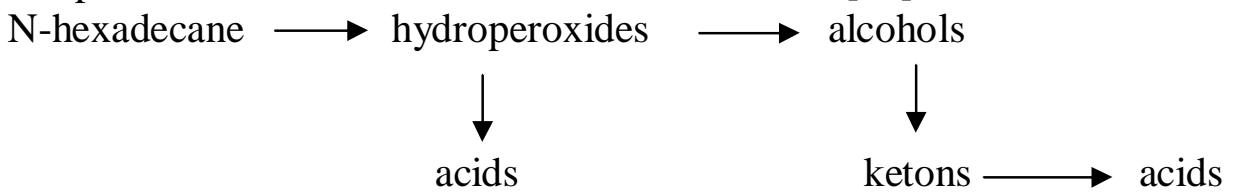

The latters are the primary intermediate the formation of further products. compounds and their decomposition leads to

\section{Conclusion}

The kinetic regularities of the reaction of liquid-phase oxidation of n-hexadecane in the presence of complexes of o-phenanthroline with metals of variable valence were studied. It is established that the presence of ophenanthroline in the catalytic system opens up new ways of regulating and controlling the oxidation of paraffin hydrocarbons. By varying the ratio of organic ligand to metal, the process can be directed towards the formation of one of the target products, with suppressing undesirable parallel reactions.

The results obtained make it possible to add o-phenanthralin to the catalytic system as an organic ligand in the reactions of liquidphase oxidation of aliphatic hydrocarbons in order to obtain mainly one or two oxygencontaining products.

\section{References}

1. Humbatova S.F., Mammadova S.M., Tapdigov Sh.Z., Safarov N.A., Abbasov M.H., Zeynalov N.A. Research into structure of argentium nanoparticles obtained from varied polymer medium. Chemical Problems. 2018, no 1, pp. 78-85.

2. Mammadova S.M., Tapdigov Sh.Z., Humbatova S.F., Safaraliyeva S.F., Hasanova M.Kh., Zeynalov N.A. Research into hydrogel swelling capacity on the basis of polyacrylic acid and immobilization of doxorubicin thereupon. Chemical Problems. 2016, no. 4, pp.377-385.

3. Mammadova S.M., Tapdigov Sh.Z., Humbatova S.F., Zeynalov N.A., Guliyeva A.R., Gasimov E.M. Research into sorbtion pproperties and structures of polymer hydrogel immobilized bydoxorubicin. Chemical Problems. 2018, no. 4, pp.316-321.

4. Suleymanova R.G., Zeynalov N.A., Badalova O.T., Kulubekova L.N., 
Kuliyeva A.R., Isazade A.F. Studying the reaction of cyclohexanone oxidation in the presence of polymeric complexes of polyethylenimine arranged to copper and nickel. Azerbaijan Chemical Journal. 2017, no. 4, pp. 55-59.

5. Suleymanova R.G., Zeynalov N.A., Badalova O.T., Kulubekova L.N., Kuliyeva A.R., Isazade A.F. Research into reaction of liquid-phase oxidation of cyclohexanone on metalpolymer complexes. Chemical Problems. 2017, no. 4, pp. 442-446.

6. Artemov A.V. New highly effective catalysts for liquid-phase oxidation processes. Kataliz v promyshlennosti, 2000, no. 2, pp.18-23. (In Russian).

7. Aqafonov E.D., Arlovskaya N.F. Mathematical simulation of hexadecane oxidation processes.

Tomsk State University Journal of Control and Computer Science. 2013, no. 4, (25), pp. 5-15.

8. Suleymanova R.G., Zeynalov N.A.,

9. Badalova O.T., Kulubekova L.N., Sharifzade N.F., Kuliyeva A.R.
Liquid-phaze oxidation of aliphatic hydrocarbons in a presence of metalpolymer complexes. Azerbaijan Chemical Journal. 2016, no. 4, pp. 8084.

10. Emanuel O.N., Skibida I.P., Maizus Z.K. Complex compounds of phenanthroline as a catalyst for the oxidation of ethylbenzene. Bulletin of the Russian Academy of Sciences. Chemistry. 1971, no. 10, pp. 24122417.

11. Emanuel O.N., Saxarov A.M., Skibida I.P. Mechanism of the catalytic effect of copper complexes with ophenanthroline in autooxidation reactions. Bulletin of the Russian Academy of Sciences. Chemistry. 1975, no. 12, pp. 2692-2696.

12. Ragimova A.M., Skibida I.M., Smirnova O.V., Suleymanova R.G., Sarkisova E.I. On the effect of o-phenanthroline on the kinetic laws of catalytic oxidation of n-decane. Azerbaijan Chemical Journal. 1981, no. 4, pp. 35-37.

\section{METALKOMPLEKS KATALIZATORLARIN ISTTIRAKI IL O n-HEKSADEKANIN KATALITIK OKSIDLOŞMӘ REAKSIYASININ KINETIK QANUNAUYĞUNLUQLARININ TODQIQI}

\section{R.H. Süleymanova, N.A. Zeynalov, O.T. Bodolova, L.N. Qulubəyova, A.R. Quliyeva, N.A. Korimova}

AMEA akademik M.Nağlyev adına Kataliz vo Qeyri-üzvi Kimya İnstitutu AZ 1143, Bakı ş. H.Cavid pr. 113, e-mail: suleyman.rena@gmail.com

Dəyişkən valentli metal komplekslar mühitindo n-heksadekanın katalitik oksidloşmə reaksiyasının kinetik qanunauyğunluqları öyranilmişdir. Katalizator qarışığı kimi ofenatrolinin dəyişkən valentli metalların ştearatları ilo alınan komplekslarindən istifado olunmuşdur. Müzyyən edilmişdir ki, o-fenantrolin metal ionlarının aktivliyina nəzərə çarpacaq dəracədə təsir ğöstərir. Katalizator qarışı̆̆ına üzvi liqandı daxil etməklə və həmçinin onun metal duzuna nisbətini dəyişməkla reaksiyanın gedişini vo xarakterinin təmzimləmək mümkündür. Metalkompleks katalizatorlarının katalitik aktivliyinin öyrənilməsi maye fazada oksidloşmə reaksiyalarının istifado olunmasında böyük imkanlar yaradır.

Açar sözlor: n-heksadekan, oksidloşmə, liqand, o-fenantrolin, metalkompleks katalizatorları, metal, oksigen, maye faza, kompleks. 


\section{ИССЛЕДОВАНИЕ КИНЕТИЧЕСКИХ ЗАКОНОМЕРНОСТЕЙ КАТАЛИТИЧЕСКОГО ЖИДКОФАЗНОГО ОКИСЛЕНИЯ Н-ГЕКСАДЕКАНА В ПРИСУТСТВИИ МЕТАЛЛОКОМПЛЕКСНЫХ КАТАЛИЗАТОРОВ}

\section{Р.Г. Сулейманова, Н.А. Зейналов, О.Т. Бадалова, Л.Н. Кулибекова, А.Р. Кулиева, Н.А. Керимова}

Институт Катализа и Неорганической Химии имени академика М. Нагиева Наииональной АН Азербайджана

AZ 1143 Баку, пр.Г. Джавида, 113, e-mail: suleyman.rena@gmail.com

Изучены кинетические закономерности каталитического окисления н-гексадекана в присутствии комплексов металлов переменной валентности. $B$ качестве каталитической системы были использованы комплексы о-фенантролина со стеаратами металлов переменной валентности $\left(\mathrm{Mn}^{2+}, \mathrm{Cu}^{2+}, \mathrm{Co}^{2+}\right)$. Установлено, что о-фенантролин оказывает существенное влияние на каталитическую активность иона металла. Введение в каталитическую систему органического лиганда, а также варьирование соотношения лиганд: соль металла оказывают существенное влияние на ход и характер протекания прочесса.

Ключевые слова: н-гексадекан, окисление, лиганд, о-фенантролин, металлокомплексные катализаторы, метал, кислород, жидкая фаза, комплекс 